\title{
CGRP antagonist infused into the bed nucleus of the stria terminalis impairs the acquisition and expression of context but not discretely cued fear
}

\author{
Kelly S. Sink, Michael Davis, and David L. Walker ${ }^{1}$ \\ Yerkes National Primate Research Center, Emory University, Atlanta, Georgia 30329, USA
}

\begin{abstract}
Calcitonin gene-related peptide (CGRP) infusions into the bed nucleus of the stria terminalis (BNST) evoke increases in startle amplitude and increases in anxiety-like behavior in the plus maze. Conversely, intra-BNST infusions of the CGRP antagonist $\mathrm{CGRP}_{8-37}$ block unconditioned startle increases produced by fox odor. Here we evaluate the contribution of CGRP signaling in the BNST to the development and expression of learned fear. Rats received five pairings of a 3.7-sec light and footshock and were tested for fear-potentiated startle one or more days later. Neither pre-training (Experiment 1) nor pre-test (Experiment 2) infusions of the CGRP antagonist CGRP ${ }_{8-37}(800 \mathrm{ng} / \mathrm{BNST}$ ) disrupted fear-potentiated startle to the 3.7-sec visual cue. However, in both experiments, $\mathrm{CGRP}_{8-37}$ infusions disrupted baseline startle increases that occurred when rats were tested in the same context as that in which they previously received footshock (Experiment 3). Intra-BNST CGRP ${ }_{8-37}$ infusions did not disrupt shock-evoked corticosterone release (Experiment 4). These data confirm previous findings implicating BNST CGRP receptors in fear and anxiety. They extend those results by showing an important contribution to learned fear and, specifically, to fear evoked by a shock-associated context rather than a discrete cue. This pattern is consistent with previous models of BNST function that have posited a preferential role in sustained anxiety as opposed to phasic fear responses. More generally, the results add to a growing body of evidence indicating behaviorally, possibly clinically, relevant modulation of BNST function by neuroactive peptides.
\end{abstract}

The bed nucleus of the stria terminalis (BNST) has emerged as an integral component of the neural circuitry that regulates unconditioned anxiety (e.g., Fendt et al. 2003, 2005b; Sink et al. 2011; Gomes et al. 2012; Xu et al. 2012), various behavioral stress effects (Morilak et al. 2003; Hammack et al. 2004; Bangasser et al. 2005; Roman et al. 2012; Davis and Walker 2013), and certain types of conditioned fear responses (c.f., Walker et al. 2009). As part of the "extended amygdala" (Alheid and Heimer 1988; Alheid et al. 1995), the BNST has rich connections with other brain regions that have been classically associated with stress, fear, and anxiety. The BNST receives many inputs from, for example, the amygdala (c.f., Dong et al. 2001a) and projects to a variety of other brain areas that regulate autonomic, neuroendocrine, and behavioral responses associated with fear (e.g., Holstege et al. 1985; Gray and Magnuson 1987, 1992; Moga et al. 1989; Peyron et al. 1998; Dong et al. 2000, 2001b; Dong and Swanson 2004).

A rich and varied population of neuroactive peptides and their receptors are found in the BNST. Many of these systems are responsive to stress (c.f., Hokfelt 1991; Hokfelt et al. 2000) and, as such, are potential therapeutic targets for stress-related pathologies. A large body of evidence has pointed to corticotropinreleasing factor (CRF) as one such peptide (Chappell et al. 1986; Lee and Davis 1997; Nagashima et al. 2003; Cooper and Huhman 2005; Hishinuma et al. 2005; Choi et al. 2006; Sahuque et al. 2006; Santibanez et al. 2006; Lee et al. 2008; Shepard et al. 2009; Sterrenburg et al. 2011; Lebow et al. 2012), and more recent data have suggested an important role for pituitary adenylate cyclase-activating peptide (PACAP) as well (Hammack et al. 2009, 2010; for possible clinical relevance also see Ressler et al. 2011; Almli et al. 2013; Jovanovic et al. 2013).

\footnotetext{
${ }^{1}$ Corresponding author

E-mail dlwalke@emory.edu

Article is online at http://www.learnmem.org/cgi/doi/10.1101//m.032482.113.
}

As with CRF (Lee and Davis 1997) and PACAP (Hammack et al. 2009), intra-BNST infusions of calcitonin gene-related peptide (CGRP) evoke fear and anxiety-like responses in animal models (i.e., increased startle and open-arm avoidance in the plus maze) and a pattern of fos activation consistent with anxiety (Sink et al. 2011). The effects of CGRP and CRF appear to be related. CRF neurons in the BNST are contacted by CGRP-positive terminals (Ju 1991; Kozicz and Arimura 2001), and we have found that the aforementioned behavioral effects of intra-BNST CGRP infusions are disrupted by siRNA knockdown of CRF in BNST neurons, and also by systemic administration as well as intra-BNST infusions of CRF-R1 antagonists (Sink et al. 2013).

To date, though, there has been almost no evaluation of CGRP receptor antagonists themselves as potential tools for anxiety reduction. Kocorowski and Helmstetter (2001) reported a modest suppression of freezing to an aversive context when a CGRP antagonist was infused into the amygdala prior to training, but similar effects were noted for CGRP itself and neither effect was dose dependent (across a 1,000,000-fold range). A modest disruption of freezing evoked by a shock-paired tone but not the shockassociated context was also noted when the antagonist was infused prior to testing. More recently, we found that intra-BNST infusions of the peptide antagonist $\mathrm{CGRP}_{8-37}$ completely blocked startle increases produced by trimethylthiazoline (TMT) (Sink et al. 2011). TMT is a chemical constituent of fox feces, and many have interpreted the behavioral effects in rodents as an innate anxiety response to predator odor (c.f., Fendt et al.

\footnotetext{
(C) 2013 Sink et al. This article is distributed exclusively by Cold Spring Harbor Laboratory Press for the first 12 months after the full-issue publication date (see http://learnmem.cshlp.org/site/misc/terms.xhtml). After 12 months, it is available under a Creative Commons License (Attribution-NonCommercial 3.0 Unported), as described at http://creativecommons.org/licenses/by-nc/ $3.0 \%$
} 
2005a; Ayers et al. 2013). Others, however, have interpreted the effects more simply as an aversion to high concentrations of a noxious odor (c.f., Dielenberg and McGregor 2001; Blanchard et al. 2003).

In addition to its role in emotional behaviors, the BNST also regulates hypothalamic-pituitary-adrenal (HPA) activity (Cullinan et al. 1993; Gray et al. 1993; Herman et al. 1994; Herman and Cullinan 1997; Sullivan et al. 2004; Choi et al. 2007, 2008a,b; Green et al. 2007). Because intra-BNST CGRP infusions increase fos immunoreactivity in the paraventricular nucleus of the hypothalamus (Sink et al. 2011)—a nodal point in the HPA axis-and because HPA activity can influence fear learning and expression (Roozendaal 2002; Aerni et al. 2004; Donley et al. 2005; Schelling et al. 2006; Soravia et al. 2006; Tronel and Alberini 2007; Taubenfeld et al. 2009; Jovanovic et al. 2011; Zohar et al. 2011; Atsak et al. 2012; de Oliveira et al. 2013), we also examined the contribution of BNST CGRP receptors to shockinduced corticosterone release.

In brief then, the goals of this study were to determine if BNST CGRP receptors participate in the development and expression of learned fear, and in stress-induced activation of the HPA axis.

\section{Results}

\section{Cannula tip placements}

Cannula tip placements for rats whose data are included in the primary analyses below are depicted in Figure 1.

\section{Experiment 1: CGRP $_{8-37}$ infused into the BNST before training attenuates} fear-potentiated startle to the context but not to the 3.7-sec visual cue The experimental timelines for Experiments 1 and 2 are shown in Figure 2. To assist with interpretation of the test data that follows, Figure 3 shows the time course of startle for vehicle-infused rats from both experiments for the first 20 trials of the pre-

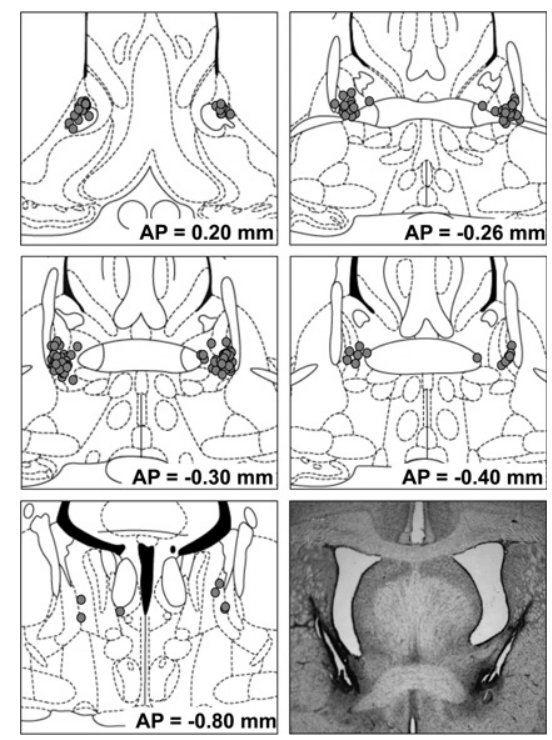

Figure 1. Cannula tip placements of rats whose data are included in behavioral and corticosterone analyses. Circles indicate intra-BNST placements; squares indicate placements in Experiment 3 that did not meet inclusion criteria. The approximate distance posterior to bregma in millimeters is indicated to the lower right of each figure. Coronal sections are adopted from Paxinos and Watson (1998), with permission from Elsevier (c) 1998.

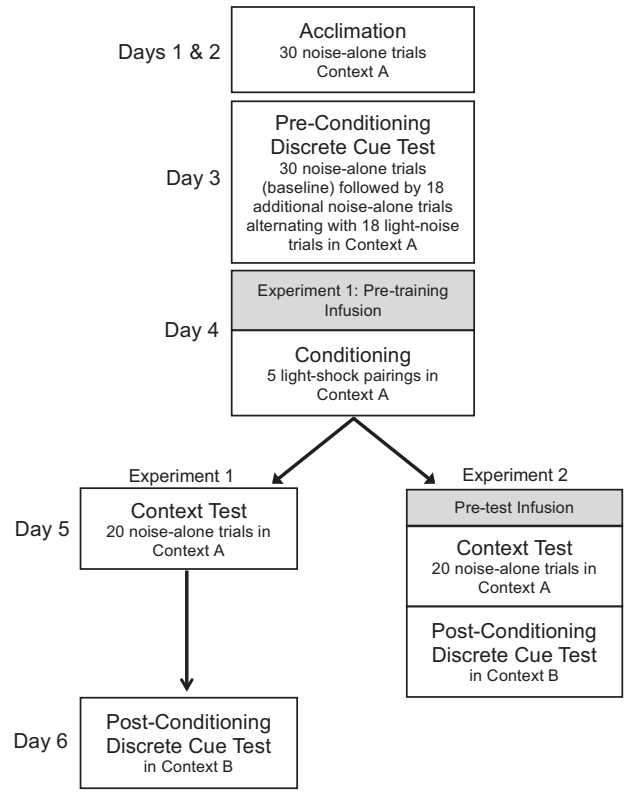

Figure 2. Sequence and outline of behavioral procedures for Experiments 1 and 2 .

conditioning test (i.e., test trials without the 3.7 -sec visual stimulus) and the 20 test trials of the post-conditioning context test, as well as the difference between the two (a measure of potentiation). That figure shows an increase in "baseline" startle when rats were tested $24 \mathrm{~h}$ after footshock, and also the decay of this increase as the test session wore on (as might be expected due to within-session extinction). The decrease of startle potentiation across trials was verified statistically with repeated-measures ANOVA on the difference scores, which showed a significant effect of Trial Number, $F_{(19,741)}=3.13$, and a significant linear trend, $F_{(1,44)}=11.73$. Moreover, single-sample $t$-tests (using a Bonferoni correction to control the error rate, effectively setting the per comparison $\alpha$ to 0.0025 ) indicated significant potentiation (i.e., vs. $0 \%$ potentiation) for trials $1-4,7$, and $18, t_{(39)}=5.87,3.33,3.57,3.74$, 3.74 , and 3.52, respectively. Because potentiation became unreliable after the fourth test trial (i.e., after 2 min of shock-free context exposure), we include between-group comparisons for context fear using not only all 20 test trials, but also the first four trials only. We did not observe similar decreases of fear-potentiated startle to the 3.7-sec visual cue (data not shown), which is not surprising given that the total duration of shock-free exposure to the light was much less-only $133 \mathrm{sec}$.

For the first four test trials, startle potentiation was significantly lower in rats infused with the CGRP receptor antagonist prior to training compared to rats infused with vehicle prior to training, based on both percent change (i.e., from preto post-conditioning), $t_{(21.4)}=2.80$, and $\log$ (i.e., $\log$ [post-shock startle amplitude/pre-shock startle amplitude] scores), $t_{(23.4)}=$ 2.24 (see Table 1 and Fig. 4A). Log scores are included as they are often recommended for these types of data (see Keene 1995) and have previously been reported by our laboratory (Miles et al. 2011). As the session wore on, potentiation scores of the two groups converged such that the overall difference was not statistically significant. Fear-potentiated startle to the 3.7-sec light was not affected by pre-training antagonist infusions using either measure (percent change or log [see Table 1]), nor were there any detectable effects on shock reactivity (4.16 \pm 0.39 vs. $4.64 \pm 0.31$ startle units for vehicle- and antagonist-infused groups, respectively). 


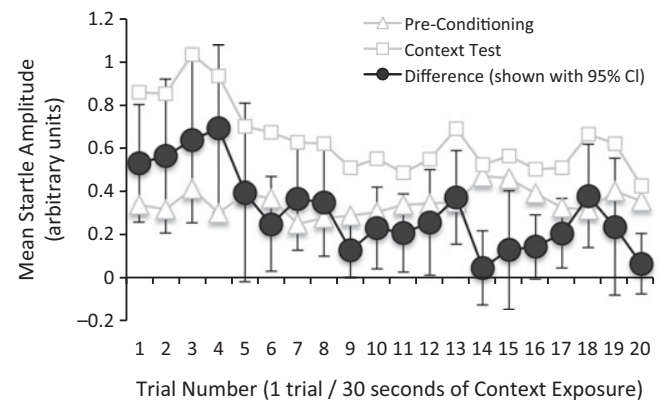

Figure 3. Startle amplitude across trials before and after fear conditioning. For all vehicle-infused rats from Experiments 1 and 2, mean startle amplitudes for the first 20 trials of the Pre-Conditioning Test are shown, together with mean startle amplitude from all 20 trials of the Post-Conditioning Context Test. The difference between startle amplitude from the pre- to post-conditioning test is also shown, together with $95 \%$ confidence intervals (i.e., overlap of the error bars with 0 on the $x$-axis indicates that the difference for that trial was not statistically significant). The increase in startle from the pre- to post-conditioning context test was most pronounced during the first 2 min of the test, but by the fifth startle response had become unreliable.

Experiment 2: $\mathrm{CGRP}_{8-37}$ within the BNST attenuates fear expression to context and 3.7-sec visual cue

As indicated in Table 1 and shown in Figure 4B, rats that received CGRP $_{8-37}$ infusions prior to testing showed significantly less fearpotentiation to the context based not only on the first four trials, $t_{(33.8)}=2.31$ and $t_{(37.4)}=2.05$ (for percent change and log scores, respectively), but also for all 20 analyzed trials, $t_{(33.45)}=2.61$ and $t_{(33.98)}=2.54$ (for percent change and log scores, respectively). As with pre-training infusions, there was no detectable effect on fear-potentiated startle to the 3.7-sec visual cue (see Table 1). Thus, the decrease in startle amplitude was specific to shockrelated "baseline" increases which could reflect, in principal, either context-evoked fear or nonassociative sensitization.

\section{Experiment 3: Do baseline startle increases reflect fear} to the shock-associated context?

As shown in Figure 5, rats trained and tested in the same context showed, overall, a statistically significant $\left(t_{(15)}=2.54, P=0.02\right.$ vs. $0 \%$ potentiation) increase in startle amplitude from before to after conditioning $(100 \pm 40.7 \%$, mean \pm SEM). The increase for the first four trials only was similar in magnitude $(85.9 \pm 44 \%)$, but just missed significance, $t_{(15)}=2.02, P=0.06$. In contrast, rats trained and tested in different contexts showed a much smaller, nonsignificant increase of $22.7 \pm 13 \%$ ( $16 \pm 18.4 \%$ for the first four trials only). Although the between-group difference did not reach significance $(P=0.07$ and 0.14 for all trials and the first four trials, respectively), the large nominal difference suggests that the primary, though perhaps not exclusive, contributor to these increases was context-evoked fear. There was little, if any, effect of the context manipulation on fear-potentiated startle to the 3.7-sec visual stimulus.

\section{Experiment 4: $\mathrm{CGRP}_{8-37}$ within the BNST does not affect stress-induced corticosterone release}

As shown in Figure 6, plasma corticosterone increased markedly in both groups after footshock exposure. ANOVA indicated a significant effect of Stress Level (i.e., before vs. after shock), $F_{(1,14)}=75.25$, but no Treatment $\times$ Shock interaction, $F_{(1,14)}=$ 0.7 . Thus, there was no discernible influence of $\mathrm{CGRP}_{8-37}$ on shock-induced corticosterone release.

\section{Discussion}

We investigated the role of CGRP signaling in the BNST in the acquisition and expression of fear memories cued by discrete and contextual stimuli, and in shock-induced corticosterone release. To do so, we infused the CGRP receptor antagonist $\mathrm{CGRP}_{8-37}$ into the BNST just prior to fear conditioning, fear testing, or footshock stress. $\mathrm{CGRP}_{8-37}$ significantly disrupted the acquisition and also expression of fear to the shock-associated context, but did not affect fear learning or expression to the 3.7-sec light that was explicitly paired with shock. There were no effects on shock-induced corticosterone release.

The effect of pre-training infusions (Experiment 1) was most apparent during the early part of the test. As fear decayed in the control group, possibly due to within-session extinction, so too did the difference between drug-and vehicle-treated rats. What appeared to be a gradual increase in fear-potentiated startle in drug-infused rats as the session wore on (e.g., compare response on first four trials vs. all 20 trials in Fig. 4A) also contributed to the loss of between-group differences during the latter part of the test. It is possible that pre-training $\mathrm{CGRP}_{8-37}$ affected the ease and rapidity with which the fear memory was recalled without, at a fundamental level, affecting its "storage." It is also possible that, as the session continued, there was a growing "awareness" of danger even if the specific memory of shock in the context was

Table 1. Mean ( \pm SEM) startle amplitude (arbitrary units) in the presence (conditioned fear) or absence (baseline) of the fear stimulus-i.e., either the context or the 3.7-sec light after conditioning

\begin{tabular}{|c|c|c|c|c|c|c|c|c|}
\hline & Baseline & $\begin{array}{c}\text { Conditioned } \\
\text { fear }\end{array}$ & $\begin{array}{l}\text { Percent } \\
\text { change }\end{array}$ & $\begin{array}{l}\text { Log } \\
\text { difference }\end{array}$ & Baseline & $\begin{array}{c}\text { Conditioned } \\
\text { fear }\end{array}$ & $\begin{array}{l}\text { Percent } \\
\text { change }\end{array}$ & $\begin{array}{c}\text { Log } \\
\text { difference }\end{array}$ \\
\hline & \multicolumn{8}{|c|}{ Pre-training infusions } \\
\hline & \multicolumn{5}{|c|}{ Vehicle infusions $(N=15]$} & \multicolumn{3}{|c|}{ CGRP $_{8-37}$ infusions $[N=11]$} \\
\hline Context (first four trials) & $0.33 \pm 0.04$ & $0.68 \pm 0.1$ & $132.7 \pm 32.6$ & $0.29 \pm 0.08$ & $0.41 \pm 0.08$ & $0.5 \pm 0.1$ & $31.2 \pm 18.8^{*}$ & $0.07 \pm 0.07 *$ \\
\hline Context (full session) & $0.33 \pm 0.03$ & $0.57 \pm 0.08$ & $82.5 \pm 24.7$ & $0.21 \pm 0.06$ & $0.37 \pm 0.07$ & $0.54 \pm 0.09$ & $61 \pm 20.3$ & $0.17 \pm 0.06$ \\
\hline \multirow[t]{3}{*}{ 3.7-sec light } & $0.62 \pm 0.12$ & $1.26 \pm 0.26$ & $99.6 \pm 18.2$ & $0.28 \pm 0.05$ & $0.5 \pm 0.13$ & $1.18 \pm 0.37$ & $112.7 \pm 25.5$ & $0.3 \pm 0.05$ \\
\hline & \multicolumn{8}{|c|}{ Pre-test infusions } \\
\hline & \multicolumn{5}{|c|}{ Vehicle infusions $(N=25)$} & \multicolumn{3}{|c|}{ CGRP $_{8-37}$ infusions $(N=16)$} \\
\hline Context (first four trials) & $0.33 \pm 0.03$ & $1.13 \pm 0.22$ & $310 \pm 80$ & $0.45 \pm 0.08$ & $0.33 \pm 0.05$ & $0.56 \pm 0.08$ & $109.2 \pm 39.5^{*}$ & $0.22 \pm 0.08$ \\
\hline Context (full session) & $0.31 \pm 0.02$ & $0.68 \pm 0.09$ & $128.5 \pm 30.6$ & $0.29 \pm 0.05$ & $0.35 \pm 0.04$ & $0.48 \pm 0.07$ & $42 \pm 14.8^{*}$ & $0.11 \pm 0.06$ \\
\hline 3.7-sec light & $0.58 \pm 0.09$ & $0.82 \pm 0.12$ & $49.5 \pm 11.7$ & $0.15 \pm 0.03$ & $0.51 \pm 0.08$ & $0.68 \pm 0.12$ & $33.5 \pm 9.7$ & $0.11 \pm 0.03$ \\
\hline
\end{tabular}

Note that the indicated percent change and log difference scores were calculated as the mean of individual rat's baseline and conditioned fear scores, and, as such, are close to but not strictly equivalent to the percent change and log difference scores that would be derived from the mean baseline and mean conditioned fear scores shown above.

$(*) P<0.05$ vs. vehicle condition (calculated for percent change and log difference scores), $t$-test. 
A Pre-Training Infusions

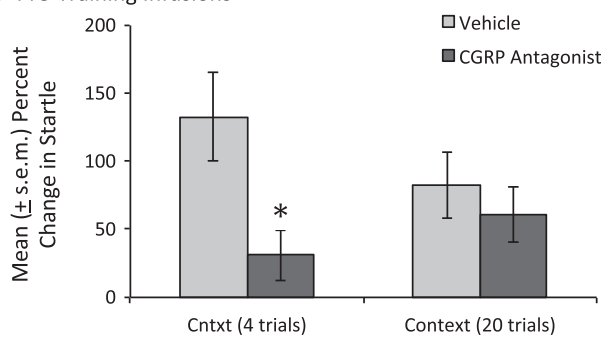

B Pre-Test Infusions

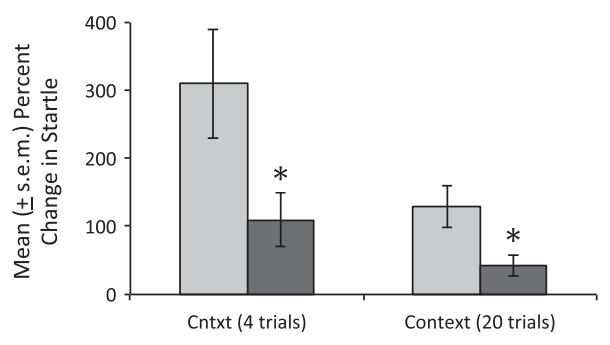

Fear Stimulus

Figure 4. Effect of intra-BNST CGRP ${ }_{8-37}$ infusions on fear learning and expression. $(A)$ When infused prior to training, the CGRP receptor antagonist significantly disrupted startle increases during the first 2 min of context exposure (i.e., the first four trials), though this difference was not maintained over the course of the entire session. (B) When infused prior to testing, the CGRP receptor antagonist significantly disrupted startle increases during the first $2 \mathrm{~min}$ of context exposure as well as the full test (note that the scaling of $B$ is different to accommodate the greater range of scores). $\left(^{*}\right) P<0.05$ vs. vehicle-infused rats.

lost. We have previously seen evidence that initially absent context fear can emerge during testing following the introduction of discrete fear stimuli that were also presented during training (Walker and Davis 2002b). As in the present study, those observations were made in animals that had had conditioning degraded (in that case, by pre-training intra-amygdala infusions of an NMDA receptor antagonist). It should also be noted that approximately half of the apparent increase in potentiated startle in the antagonist-treated group was actually due to a somewhat atypical decrease in pre-conditioning baseline startle from the first four trials to all 20 trials (i.e., from 0.41 to 0.37 units, see Table 1), rather than a trial-dependent increase during the post-conditioning context test. However the effect should best be interpreted, the apparent disruption of post-conditioning increases early in the test session did not appear to be secondary antagonist effects on shock perception during training insofar as shock reactivity was comparable in drug- and vehicle-treated rats; nor did it appear secondary to attenuated HPA-axis activation as this too was normal, as judged by corticosterone levels (Experiment 4). Thus, pre-training CGRP receptor antagonist infusions into the BNST appeared to disrupt, but not fully block, the post-conditioning increases in startle that were shown in Experiment 3 to reflect context fear.

The effect of pre-test infusions (Experiment 2) was similar in that it too was restricted to fear evoked by the context, but arguably more robust in that it was fully apparent, and statistically significant, across the entire test session. As is evident from Figure 4, potentiation in vehicle-infused rats was considerably larger during the first four trials of this experiment than potentiation during the first four trials of Experiments 1 and 3. The only procedural difference is that rats in Experiment 2 were handled and briefly restrained just prior to testing as part of the infusion procedure. Perhaps, then, part of $\mathrm{CGRP}_{8-37}$ 's initial effect included a reduction of the effect on startle of this putative stressor. Whatever the reason for the large level of startle potentiation during the first four trials, the effect (or at least the difference) appeared shortlived, as startle potentiation overall (i.e., to all 20 trials) was comparable to that observed in Experiments 1 and 3. Even against this more normal baseline, $\mathrm{CGRP}_{8-37}$ significantly disrupted startle potentiation on noise alone trials without affecting startle potentiation by the discrete cue (i.e., the $3.7-\mathrm{sec}$ light). We have also found that intra-BNST CGRP ${ }_{8-37}$ infusions do not affect startle amplitude on noise alone trials in nonfearful rats (Sink et al. 2011). Thus, we believe that the observed effect reflects a specific disruption of startle increases produced by the conditioning procedure, as opposed to a nonspecific reduction of startle in general.

The results of Experiment 3 confirmed that pre- to postconditioning startle increases were largely context dependent. An unexpected observation from this experiment was that, for these animals only, startle remained elevated for the duration of the post-conditioning test (i.e., there was no decline after the first few trials). It is possible that the infusions during Experiments 1 and 2 served as a unique cue that allowed rats to quickly discriminate between training and test sessions. Perhaps more likely is the possibility that damage to the BNST caused by cannula implantation itself may have impaired the ability of rats to maintain the fear response. In fact, unpublished results from our laboratory show that cannula implantation into the central nucleus of the amygdala produces a relatively modest but statistically significant decrease of fear-potentiated startle to 3.7-sec light CSs. In the experiments reported here, involving the BNST, just the opposite result was obtained in that fear-potentiated startle to the light stimulus was preserved.

That the effect of intra-BNST CGRP ${ }_{8-37}$ (and perhaps of cannula implantation itself) would be largely specific to fear evoked by the context is consistent with the view that the BNST participates preferentially in long- as opposed to short-duration fear responses-an hypothesis we have previously advanced elsewhere (c.f., Miserendino et al. 1990; Walker and Davis 1997; Walker et al. 2009; Davis et al. 2010). Indeed, the majority of studies that have implicated the BNST in conditioned fear have done so using long-duration fear stimuli such as shock- or withdrawalassociated contexts (Aston-Jones et al. 1999; Resstel et al. 2008; Luyten et al. 2011, 2012; Ali et al. 2012; Hott et al. 2012). Several such studies have directly compared the effects of BNST manipulations on fear evoked by short-duration cues to fear evoked by longer-duration contextual (Sullivan et al. 2004; Zimmerman and Maren 2011) or unimodal (Waddell et al. 2006) cues. Both within and across studies, BNST manipulations

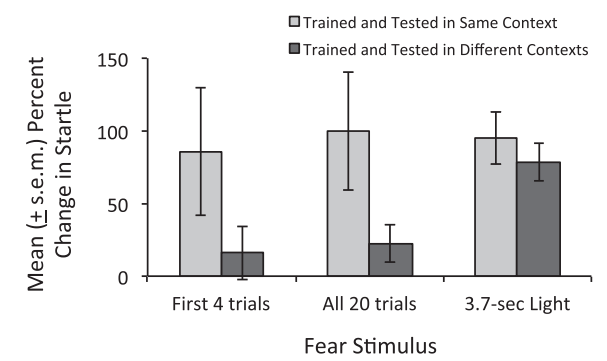

Figure 5. Fear-potentiated startle as a function of similarity between shock and test contexts. Rats received light-shock pairings in one of two distinctive contexts (A or B) and were tested in B (i.e., the same context as for all other rats in this study). The baseline startle increase observed in rats trained and tested in the same context was largely eliminated when rats were trained and tested in different contexts, suggesting that they are primarily attributable to context fear. There was little, if any, effect on fear-potentiated startle to the $3.7-\mathrm{sec}$ visual stimulus. 


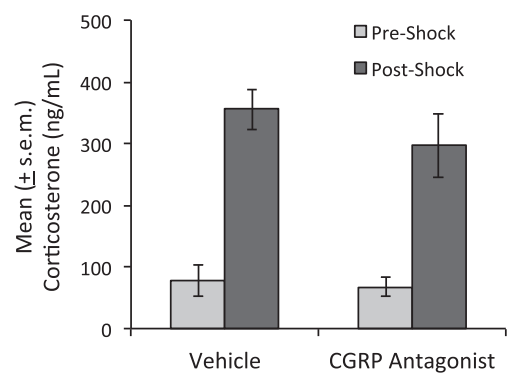

Figure 6. Effect of intra-BNST CGRP ${ }_{8-37}$ on stress-induced HPA activation. ANOVA indicated a significant effect of Stress (pre-shock to postshock) but no significant Treatment effect or Treatment $\times$ Stress interaction. Thus, $\mathrm{CGRP}_{8-37}$ did not disrupt the increase in plasma corticosterone that followed footshock.

have generally (but see Schweimer et al. 2005) been found to more effectively disrupt long-duration fear responses, as observed in the present study.

In other studies, effects of BNST manipulations on what appear to be shock-induced nonassociative sensitization have been reported (Gewirtz et al. 1998; Davis and Walker 2013). To verify that the increases in startle that were disrupted by $\mathrm{CGRP}_{8-37}$ infusions reflected associative fear to the context rather than sensitization, other rats were trained and tested in the same or distinctively different chambers (Experiment 3). In rats trained and tested in different chambers, we observed only a small increase in baseline startle from the pre-conditioning to post-conditioning context test. Though not statistically significant (i.e., vs. $0 \%$ potentiation using a single sample $t$-test), this increase might have reflected a minor contribution of nonassociative sensitization, or possibly associative fear generated by shared elements of the training/test procedure (e.g., handling). In contrast, fear-potentiated startle to the $3.7-\mathrm{sec}$ visual stimulus that had been explicitly paired with shock was not affected (at least not noticeably so) by the context shift. This result verifies that there was not something about conditioning in Context B that generally produced lower levels of fear learning. Thus, the data, while expected, provide an important positive control.

One limitation of our study concerns the precision with which we are able to identify the anatomical locus of CGRP ${ }_{8-37}$ 's effects. In particular, the possibility that $\mathrm{CGRP}_{8-37}$ 's actions were mediated by receptors outside the BNST cannot be wholly dismissed. However, the fact that CGRP receptor populations are highly localized to discrete discontiguous areas very much limits the number of possible alternatives. Based on proximity, the most likely alternative (i.e., to the BNST) would be that CGRP $_{8-37}$ was acting on receptors just ventral and lateral to the BNST as this area also contains significant numbers of CGRP receptors (Skofitsch and Jacobowitz 1985; Kruger et al. 1988; Christopoulos et al. 1995). This population is continuous with that found in the BNST and, as such, it would be difficult to compare these alternatives by evaluating the effect of infusions into the two areas (i.e., it is likely that we are blocking some of these receptors with intra-BNST infusions, and equally likely that infusions into this alternative area would influence BNST CGRP receptors). We have previously found, however, that infusions of CGRP itself $\left(\mathrm{CGRP}_{8-37}\right.$ should have very similar diffusion characteristics as it is structurally identical to CGRP but without the first seven amino acids) just dorsal to the BNST or into the adjacent lateral ventricle did not increase startle as intra-BNST infusions did in that study (Sink et al. 2011). Thus, we believe it likely that the effects of $\mathrm{CGRP}_{8-37}$ observed here are most likely attributable to actions within and/or very near to the site of infusion.
In a similar vein, it should be noted that the BNST is not itself a homogenous area but consists of many different subdivisions (see Dong et al. 2001a), of which some, or each, may make different contributions to behavior. To dissect out the individual contributions of these areas, more advanced techniques, such as optogenetic stimulation, will be especially valuable. In fact, results from the first such studies have now been reported (Jennings et al. 2013; Kim et al. 2013). Findings from Kim et al. (2013) are especially relevant to this discussion. Their results are consistent with what we and others have found (i.e., that the BNST as a whole promotes anxiety), as determined in their laboratory by the anxiolytic effects on plus-maze behavior of intra-BNST NBQX + AP5 infusions (i.e., an ionotropic glutamate receptor antagonist cocktail). They also found, however, that this general role belied a more complex interplay between subdivisions that was only revealed by optogenetic manipulation of specific nuclei and pathways. In particular, they identified an anxiety-suppressing influence of the anterodorsal BNST and an anxiety-promoting influence of the BNST's oval nucleus.

We also do not know if endogenous CGRP provides a necessary basal tone of receptor activation or if, instead, CGRP serves a more phasic signaling function during fear conditioning and evocation. It is known that the primary source of BNST CGRP is the parabrachial nucleus (Shimada et al. 1985)—another heterogeneous area that, among its many other functions, conveys painrelated information to the "extended amygdala" including the BNST (c.f., Gauriau and Bernard 2002). Given that BNST manipulations disrupt the negative affective component of somatic as well as visceral pain (Deyama et al. 2007, 2008), it seems plausible that CGRP is involved in these effects. In fact, in the lateral capsular amygdala (i.e., a part of the amygdala that receives collateral input from BNST-projecting parabrachial neurons, e.g., Sarhan et al. [2005]), CGRP evokes pain-associated behaviors in the absence of noxious stimuli (Han et al. 2010), whereas CGRP receptor antagonists reduce pain-associated behaviors and electrophysiological responses (Han et al. 2005). Though speculative, these data suggest that CGRP receptor ligands might be especially useful for treating the negative effect that often accompanies conditions associated with chronic pain.

There is now substantial evidence of BNST activation during evoked anxiety in humans (i.e., from imaging studies [Hasler et al. 2007; Straube et al. 2007; Somerville et al. 2010, 2013; Alvarez et al. 2011; Yassa et al. 2012]), and compelling evidence that electrical stimulation of a brain area lying at the junction of the anterior capsule, anterior commissure, and posterior ventral striatum - an area which corresponds very closely to the area targeted by our cannula-markedly reduces anxiety and depression in patients with otherwise intractable obsessive-compulsive disorder (Greenberg et al. 2010). That pharmacological modulation of BNST might also prove therapeutic is an exciting prospect. The abundance of so many different peptide and peptide receptors within the BNST (e.g., Woodhams et al. 1983; Ju et al. 1989; Lesur et al. 1989; Walter et al. 1991) would seem to offer many such opportunities. Few have yet been explored.

\section{Materials and Methods}

\section{Animals}

Male Sprague-Dawley rats, weighing between 250 and $300 \mathrm{~g}$ at the time of purchase (Charles River, Raleigh, NC), were housed in groups of four in $45 \times 20 \times 24-\mathrm{cm}$ (depth $\times$ width $\times$ height) polycarbonate cages. They were maintained on a 12-h light-dark cycle (lights on at 8 a.m.) with food and water available ad libitum. Procedures typically began between 10-14 d after arrival, and in no case sooner than $7 \mathrm{~d}$. All procedures were conducted in accordance with USDA and Animal Welfare Act regulations, and with 
the approval of the Emory University Institutional Animal Care and Use Committee.

\section{Surgery}

Rats were anesthetized with $75 \mathrm{mg} / \mathrm{kg}$ (i.p.) ketamine $\mathrm{HCl}$ (Ketathesia, Butler Animal Health Supply) and $0.5 \mathrm{mg} / \mathrm{kg}$ (i.p.) dexmedetomidine $\mathrm{HCl}$ (Dexdomitor, Orion Pharma), and received an analgesic dose $(1.0 \mathrm{mg} / \mathrm{kg}$, s.c.) of meloxicam (Metacam, Boehringer Ingelheim) to reduce post-operative discomfort. Once unresponsive to tailpinch, they were placed in a Kopf Instruments stereotaxic frame with the nosebar set to $-3.8 \mathrm{~mm}$ (flat-skull position). Four jeweler screws were anchored to the skull, after which the tip of a 26-gauge guide cannula (Model C315G, Plastics One) was positioned $0.3 \mathrm{~mm}$ caudal and 3.8 $\mathrm{mm}$ lateral to bregma, and lowered $5.8 \mathrm{~mm}$ (also in reference to bregma) through a pre-drilled hole. The cannula was angled $20^{\circ}$ from vertical to avoid the lateral ventricle (see Fig. 1). This procedure was repeated on the other side of the brain, and the entire assembly cemented in place using cranioplastic powder (Plastics One). Stainless-steel wires were inserted into the guide cannula to maintain patency, with the tip of each extending $\sim 1 \mathrm{~mm}$ past the end of the guide cannula. Recovery from anesthesia was facilitated with $0.5 \mathrm{mg} / \mathrm{kg}$ atipamezole $\mathrm{HCl}$ (Antisedan, Orion Pharma). A minimum of 7 d elapsed between cannula implantation and the onset of behavioral procedures.

\section{Drugs and infusion procedure}

The CGRP antagonist, CGRP $_{8-37}$ (Tocris), was dissolved in phosphate-buffered saline with $0.1 \%$ bovine serum albumin (BSA) and frozen at $-80^{\circ} \mathrm{C}$ until the day of use. Prior to the infusions, the infusion lines (PE-20 polyethylene tubing) and injection cannulae were flushed with $0.1 \%$ BSA to prevent peptide adhesion. Vehicle or $\mathrm{CGRP}_{8-37}(800 \mathrm{ng} /$ side based on our previous experience with this compound [Sink et al. 2011]) was infused (0.5 $\mu \mathrm{L} /$ side $/ 2 \mathrm{~min}$ ) bilaterally through 32 -gauge injection cannulae (Model C315I, Plastics One). The injection cannulae were left in place for an additional 2 min to allow for diffusion, whereupon the wires were placed back into the guide cannula.

\section{Cannula placement verification}

Rats were euthanized with carbon dioxide and rapidly decapitated. The brains were removed and immersed in a 30\% (wt/vol) sucrose-formalin solution for at least $4 \mathrm{~d}$, after which $50-\mu \mathrm{m}$ coronal sections were cut through the rostrocaudal extent of the BNST. Every other section was mounted and stained with cresyl violet. A scorer blind to the animal's group assignment and behavioral data assessed cannulae placements. Data from animals with one or both cannula $>0.5 \mathrm{~mm}$ from the lateral BNST, and/or medial to the internal capsule, and/or penetrating or shearing the lateral ventricle, were not included in the primary behavioral analyses.

\section{Behavioral apparatus and stimuli}

For Experiments 1, 2, and 4, rats were shocked and tested in four identical $8 \times 15 \mathrm{~cm} \times 15 \mathrm{~cm}$ high Plexiglas and wire mesh cages, each suspended between compression springs within a steel frame located within a custom-designed sound-attenuating chamber. The floor of each cage consisted of four $6.0-\mathrm{mm}$ diameter stainless steel bars spaced $18 \mathrm{~mm}$ apart. For Experiment 3, one group of rats received footshock in a different apparatus, $30 \times 25 \mathrm{~cm} \times 25 \mathrm{~cm}$ high, consisting of one aluminum and three Plexiglas sides, a semi-open Plexiglas top, and $164.8-\mathrm{mm}$ stainless steel bars spaced $19 \mathrm{~mm}$ apart.

For testing, startle responses were evoked by $50-\mathrm{msec} 95-\mathrm{dB}$ white-noise bursts (5-msec rise-decay time, $0-22 \mathrm{kHz}$ ) generated by a Macintosh G3 computer sound file, amplified by a Radio Shack amplifier (Model MPA-200, Tandy), and delivered through Radio Shack Supertweeter speakers located $4 \mathrm{~cm}$ in front of each cage. Background noise (60-dB wideband) was produced by an ACO Pacific white-noise generator (Model 3024) and delivered through the same speakers as those used to provide the startle-eliciting white-noise bursts. Sound-level measurements were made with a Brüel \& Kjaer model 2235 sound-level meter (A scale, random input) with the microphone (Type 4176) located $10 \mathrm{~cm}$ from the center of the speaker, which approximates the distance of the rat's ear from the speaker during testing. Startle-response amplitudes were quantified using an accelerometer (Model U321AO2, PCB Piezotronics) affixed to the bottom of each cage. Cage movement (e.g., produced by the rats' startle response) resulted in displacement of the accelerometer, which in turn produced a voltage output proportional to the velocity of cage movement. This output was amplified (Model 483B21, PCB Piezotronics) and digitized on a scale of 0-9.98 units by an InstruNET device (Model 100B, GW Instruments) interfaced to a Macintosh G3 computer. Startle amplitude was defined as the maximal peak-to-peak voltage that occurred during the first $200 \mathrm{msec}$ after onset of the startle-eliciting whitenoise burst.

The conditioned stimulus (CS) was a 3.7-sec light (82 lux) produced by an 8 -W fluorescent bulb $(100-\mu$ sec rise time) located $10 \mathrm{~cm}$ behind each cage. Luminosity was measured using a VWR light meter. The unconditioned stimulus was a 0.5 -sec, 0.4-mA scrambled footshock delivered across the floor bars of the test cage. Shocks were produced by BRS/LVE shock generators (SGS-004). Shock intensity was measured with a $1-\mathrm{k} \Omega$ resistor across a differential channel of an oscilloscope in series with a $100-\mathrm{k} \Omega$ resistor connected between different floor bars within each cage. Current was defined as the root mean square voltage across the $1-\mathrm{k} \Omega$ resistor where $\mathrm{mA}=0.707 \times 0.5 \times$ peak-to-peak voltage. Footshock reactions were measured in the same way that noise-evoked startle responses were measured with the exception that the accelerometer's output was sampled for 500 rather than $200 \mathrm{msec}$. The presentation and sequencing of all stimuli were under the control of Macintosh G3 computer using custom-designed software (The Experimenter; Glassbeads Inc.).

\section{General behavioral procedures}

\section{Acclimation/ baseline startle test}

On each of $2 \mathrm{~d}$, rats were acclimated to the test chambers and stimuli during which time baseline startle measurements were also taken. For these sessions, rats were placed into the chambers where, after $5 \mathrm{~min}$, they were presented with 30 95-dB startle-eliciting white-noise bursts. For this and all other startle tests, the interval between noise bursts was $30 \mathrm{sec}$.

\section{Pre-training test}

On the third day, rats were given a drug-free pre-conditioning test. Five minutes after being placed into the chamber, all rats received 30 startle-eliciting noise bursts followed by 36 additional noise bursts of which half were presented $3.2 \mathrm{sec}$ after onset of the 3.7-sec visual stimulus (light-noise trial type) and half presented, on alternate test trials, without the light (noise alone trial type). The data from this session were used to assign rats to different treatment groups such that the mean startle level of each treatment group for both trial types prior to conditioning was comparable. In general, however, there was no effect of the light prior to conditioning (for all animals included in this study, the mean \pm SEM percent change in startle amplitude from trials without the 3.7 -sec visual stimulus to trials with the visual stimulus, prior to fear conditioning, was $2.3 \%+2.9 \%)$.

\section{Fear conditioning}

On the following day, rats received five light-shock pairings, the first of which occurred $5 \mathrm{~min}$ after the rats were placed into the startle apparatus. Subsequent pairings occurred every $3 \mathrm{~min}$ such that the total session length was $20 \mathrm{~min}$. For each pairing, the 0.5 -sec shock was delivered $3.2 \mathrm{sec}$ after onset of the $3.7-\mathrm{sec}$ visual CS. 


\section{Test for context fear}

On the following day, rats were placed into the test chamber, where they received 20 startle-eliciting noise bursts. The first noise burst occurred within $30 \mathrm{sec}$ of the rat being placed into the cage and successive noise bursts occurred, as always, at an inter-trial interval of $30 \mathrm{sec}$.

\section{Test for cued fear to the visual CS}

Twenty-four hours (Experiment 1) or several minutes (Experiments 2) later, rats were returned to the same chamber and tested for fear-potentiated startle to the visual CS. For this test, rats received 30 startle-eliciting noise bursts followed by 36 additional noise bursts of which half were presented $3.2 \mathrm{sec}$ after onset of the 3.7-sec visual stimulus (light-noise trial type) and half presented, on alternate test trials, without the light (noise alone trial type). For rats in Experiment 3, the context and discretely cued fear tests were continuous. Thus, rats were placed into the test cage and within the first minute received the first of 30 startle-eliciting noise bursts followed by 36 additional noise bursts, with half being presented $3.2 \mathrm{sec}$ after onset of the 3.7-sec visual stimulus and half being presented, on alternate test trials, without the light. Context fear was evaluated based on the first 20 noise alone trials (i.e., vs. the first 20 noise alone trials of the pre-conditioning test) and fear to the 3.7-sec visual stimulus was evaluated based on the intermixed noise alone and light-noise trials.

\section{Experiment 1: effect of CGRP antagonist on fear learning}

Rats received bilateral intra-BNST infusions of $800 \mathrm{ng} \mathrm{CGRP}_{8-37}$ $(N=11$ placements that met the inclusion criterion described in the Cannula Placement Verification section above) or vehicle ( $N=15$ verified placements) immediately prior to fear conditioning. Twenty-four hours later, they were tested for context fear and $24 \mathrm{~h}$ after that for fear-potentiated startle to the discrete cue (i.e., the 3.7-sec visual stimulus). During conditioning and testing for context fear, the chamber was scented with a 30\% acetic acid solution placed on gauze pads inside a scintillation vial, just outside the test cage. The odor was omitted for the discrete cue test and, in addition, a sandpaper insert was placed over the shock bars and 2 $5-\mathrm{cm}$ beaded chains were hung from the top of the cage (to provide a distinct somatosensory stimulus). The timeline of behavioral procedures for Experiments 1 and 2 is shown in Figure 2.

Experiment 2: effect of CGRP antagonist on fear expression Rats were fear conditioned and, $24 \mathrm{~h}$ later, received bilateral intra-BNST infusions of $800 \mathrm{ng} \mathrm{CGRP}_{8-37}(N=16$ verified placements) or vehicle ( $N=25$ verified placements). Immediately thereafter, they were tested for context fear. As in Experiment 1, the chamber was scented with acetic acid during fear conditioning and the context test. Afterward, they were briefly returned to the transport box, the acetic acid scent vials removed from the test chamber, the floor bars covered with sandpaper, and $5-\mathrm{cm}$ chains suspended from the tops of the cages. The cages were blown out with a hair dryer to dissipate any residual acetic acid odor. Rats were then returned to the test chambers for the discrete cue test.

For this experiment, the context and discrete cue tests were performed on the same day in order to avoid problems associated with a second infusion (e.g., that the response to the second infusion would be altered by the first due, for example, to receptor up-regulation or tissue damage). We previously found that intraBNST CGRP $_{8-37}$ infusions significantly disrupt CGRP-induced startle increases for up to $3 \mathrm{~h}$ (Sink et al. 2011). Because the entirety of the discrete cue test was completed within 60 min of the antagonist infusion, this fell well within the window during which CGRP $_{8-37}$ would be expected to remain active.

\section{Experiment 3: evaluation of context specificity}

To assess the degree to which post-conditioning startle increases on noise alone test trials reflected an associative fear response to the training context as opposed to nonassociative shock-induced sensitization, additional groups were shocked and tested in the same $(N=16)$ vs. different $(N=16)$ contexts. Rats in the "same" group were fear conditioned as previously described. Twentyfour hours later, they received the context and discrete cue test. Fear conditioning and testing both took place in the presence of the acetic acid scent. Rats in the "different" group were tested in the same chamber as rats in the "same" group, but fear conditioning took place in a different room and physically different chamber (described in the Behavioral Apparatus and Stimuli section above). For these animals, the acetic acid scent was present during conditioning but not testing.

\section{Experiment 4: effect of CGRP antagonist on stress-induced corticosterone release}

All rats were handled for $2 \mathrm{~min}$ per day for $3 \mathrm{~d}$ prior to blood collection to reduce baseline stress levels. On the day of the stress procedure, a baseline blood sample $(\sim 300 \mu \mathrm{L})$ was collected from the lateral tail vein (after being nicked with a scalpel) into EDTAor heparin-coated tubes, while the rat was gently restrained in a towel. Rats were then infused with either vehicle $(N=8$ verified placements) or $\mathrm{CGRP}_{8-37}(\mathrm{~N}=8$ verified placements). Ten minutes later, they received the first of five footshocks delivered at an average interval of one shock every $4 \mathrm{~min}$. Animals were decapitated $10 \mathrm{~min}$ after the final shock and trunk blood collected into EDTA-coated tubes that were subsequently centrifuged to isolate plasma. Samples were frozen at $-80^{\circ} \mathrm{C}$ until analysis. Because circulating corticosterone levels vary diurnally, all blood collections were performed between 11 a.m. and 2.30 p.m. Corticosterone was measured using the Coat-a-Count Radioimmunoassay kit (Siemens Healthcare Diagnostics), with samples run in triplicate in a single assay on the Wizard2 Gamma Counter (Perkin Elmer). Two levels of a commercial quality control serum were run with each assay.

\section{Statistical analyses}

For each rat, fear-potentiated startle to the 3.7-sec light was calculated as a ratio (mean startle on light-noise trials/mean startle on noise alone trials). Ratio measures are advantageous for startle data in that they remove variability brought about by betweenanimal baseline differences (Walker and Davis 2002a). The ratios are presented as percent change scores in the accompanying data figures. For each animal, the log of this ratio was also calculated. Log transforms of ratio data have been recommended for a variety of reasons, including normalization of skewed distributions prior to parametric analyses (for a concise review, see Keene 1995). Although the results of the analyses included here were not appreciably different for raw ratio vs. log-transformed scores, we include the latter for consistency with prior analyses from our group (Miles et al. 2011).

For each rat, fear-potentiated startle to the context was assessed by computing a similar ratio (mean startle level during 20 trials of Context Test/mean startle level during first 20 trials of Pre-Training Test), and its log transform. Visual inspection of the time course of startle (see Fig. 3) indicated that potentiation by the context was short-lived, possibly reflecting within-session extinction. In particular, startle elevations became statistically unreliable after the first four responses. As such, for both percent change and log scores, the data were analyzed using mean startle amplitude from the first four test trials of the Pre-Conditioning and Context Tests, as well as the mean startle amplitude from all 20 trials.

For all measures, between-group comparisons were made using Welch's modification of Student's $t$-test for independent samples (Welch 1938) which performs similarly to Student's $t$-test calculation when group variances are equal but outperforms Student's $t$-test when variances differ (Ruxton 2006). Factorial ANOVA, with Treatment as a between-subjects factor and Stress Level (before vs. after shock) as a within-subjects factor, was used for analysis of the corticosterone data. The results of single 
sample $t$-tests (for actual vs. $0 \%$ potentiation) are also reported for select groups.

Inferential statistics were performed using SPSS (version 16.0.0, SPSS, Inc.) and Graphpad Prism (version 6.0b) software.

\section{Acknowledgments}

This research was supported by NIH National Service Research Award MH093023 to K.S.S., NIH awards MH47840 and MH069056 to M.D., NIH award MH080330 to D.L.W., and a NARSAD Young Investigator Award to D.L.W. Assay services were provided by the Biomarkers Core Laboratory at the Yerkes National Primate Research Center. This project was also supported by the National Center for Research Resources P51RR000165, and is currently supported by the Office of Research Infrastructure Programs/OD P51OD011132. The content is solely the responsibility of the authors and does not necessarily represent the official views of the National Institutes of Health.

\section{References}

Aerni A, Traber R, Hock C, Roozendaal B, Schelling G, Papassotiropoulos A, Nitsch RM, Schnyder U, de Quervain DJ. 2004. Low-dose cortisol for symptoms of posttraumatic stress disorder. Am J Psychiatry 161: $1488-1490$

Alheid GF, Heimer L. 1988. New perspectives in basal forebrain organization of special relevance for neuropsychiatric disorders: The striatopallidal, amygdaloid, and corticopetal components of substantia innominata. Neuroscience 27: 1-39.

Alheid G, De Olmos JS, Beltramino CA. 1995. Amygdala and extended amygdala. In The rat nervous system (ed. Paxinos G), pp. 495-578. Academic Press, New York.

Ali AE, Wilson YM, Murphy M. 2012. Identification of neurons specifically activated after recall of context fear conditioning. Neurobiol Learn Mem 98: $139-147$.

Almli LM, Mercer KB, Kerley K, Feng H, Bradley B, Conneely KN, Ressler KJ. 2013. ADCYAP1R1 genotype associates with post-traumatic stress symptoms in highly traumatized African-American females. Am J Med Genet B Neuropsychiatr Genet 162B: 262-272.

Alvarez RP, Chen G, Bodurka J, Kaplan R, Grillon C. 2011. Phasic and sustained fear in humans elicits distinct patterns of brain activity. Neuroimage 55: 389-400.

Aston-Jones G, Delfs JM, Druhan J, Zhu Y. 1999. The bed nucleus of the stria terminalis. A target site for noradrenergic actions in opiate withdrawal. Ann N Y Acad Sci 877: 486-498.

Atsak P, Hauer D, Campolongo P, Schelling G, McGaugh JL, Roozendaal B. 2012. Glucocorticoids interact with the hippocampal endocannabinoid system in impairing retrieval of contextual fear memory. Proc Natl Acad Sci 109: 3504-3509.

Ayers LW, Asok A, Heyward FD, Rosen JB. 2013. Freezing to the predator odor $2,4,5$ dihydro 2,5 trimethylthiazoline (TMT) is disrupted by olfactory bulb removal but not trigeminal deafferentation. Behav Brain Res 253: $54-59$.

Bangasser DA, Santollo J, Shors TJ. 2005. The bed nucleus of the stria terminalis is critically involved in enhancing associative learning after stressful experience. Behav Neurosci 119: 1459-1466.

Blanchard DC, Griebel G, Blanchard RJ. 2003. Conditioning and residual emotionality effects of predator stimuli: Some reflections on stress and emotion. Prog Neuropsychopharmacol Biol Psychiatry 27: 1177-1185.

Chappell PB, Smith MA, Kilts CD, Bissette G, Ritchie J, Anderson C, Nemeroff CB. 1986. Alterations in corticotropin-releasing factor-like immunoreactivity in discrete rat brain regions after acute and chronic stress. J Neurosci 6: 2908-2914.

Choi DC, Nguyen MM, Tamashiro KL, Ma LY, Sakai RR, Herman JP. 2006. Chronic social stress in the visible burrow system modulates stress-related gene expression in the bed nucleus of the stria terminalis. Physiol Behav 89: 301-310.

Choi DC, Furay AR, Evanson NK, Ostrander MM, Ulrich-Lai YM, Herman JP. 2007. Bed nucleus of the stria terminalis subregions differentially regulate hypothalamic-pituitary-adrenal axis activity: Implications for the integration of limbic inputs. J Neurosci 27: $2025-2034$

Choi DC, Evanson NK, Furay AR, Ulrich-Lai YM, Ostrander MM, Herman JP. 2008a. The anteroventral bed nucleus of the stria terminalis differentially regulates hypothalamic-pituitary-adrenocortical axis responses to acute and chronic stress. Endocrinology 149: 818-826.

Choi DC, Furay AR, Evanson NK, Ulrich-Lai YM, Nguyen MM, Ostrander MM, Herman JP. 2008b. The role of the posterior medial bed nucleus of the stria terminalis in modulating hypothalamic-pituitary- adrenocortical axis responsiveness to acute and chronic stress. Psychoneuroendocrinology 33: 659-669.

Christopoulos G, Paxinos G, Huang XF, Beaumont K, Toga AW, Sexton PM. 1995. Comparative distribution of receptors for amylin and the related peptides calcitonin gene related peptide and calcitonin in rat and monkey brain. Can J Physiol Pharmacol 73: 1037-1041.

Cooper MA, Huhman KL. 2005. Corticotropin-releasing factor type II $\left(\mathrm{CRF}_{2}\right)$ receptors in the bed nucleus of the stria terminalis modulate conditioned defeat in Syrian hamsters (Mesocricetus auratus). Behav Neurosci 119: 1042-1051.

Cullinan WE, Herman JP, Watson SJ. 1993. Ventral subicular interaction with the hypothalamic paraventricular nucleus: Evidence for a relay in the bed nucleus of the stria terminalis. J Comp Neurol 332: 1-20.

Davis M, Walker DL. 2013. Role of bed nucleus of the stria terminalis and amygdala AMPA receptors in the development and expression of context conditioning and sensitization of startle by prior shock. Brain Struct Funct (http://link.springer.com/article/10.1007/s00429-013-0616-5/ fulltext.html)

Davis M, Walker DL, Miles L, Grillon C. 2010. Phasic vs sustained fear in rats and humans: Role of the extended amygdala in fear vs anxiety. Neuropsychopharmacology 35: 105-135.

de Oliveira AR, Reimer AE, Reis FM, Brandao ML. 2013. Conditioned fear response is modulated by a combined action of the hypothalamicpituitary-adrenal axis and dopamine activity in the basolateral amygdala. Eur Neuropsychopharmacol 23: 379-389.

Deyama S, Nakagawa T, Kaneko S, Uehara T, Minami M. 2007. Involvement of the bed nucleus of the stria terminalis in the negative affective component of visceral and somatic pain in rats. Behav Brain Res 176: 367-371.

Deyama S, Katayama T, Kondoh N, Nakagawa T, Kaneko S, Yamaguchi T, Yoshioka M, Minami M. 2008. Role of enhanced noradrenergic transmission within the ventral bed nucleus of the stria terminalis in visceral pain-induced aversion in rats. Behav Brain Res. 197: 279-283.

Dielenberg RA, McGregor IS. 2001. Defensive behavior in rats towards predatory odors: A review. Neurosci Biobehav Rev 25: 597-609.

Dong H-W, Swanson LW. 2004. Organization of axonal projections from the anterolateral area of the bed nucleus of the stria terminalis. J Comp Neurol 468: 277-298.

Dong HW, Petrovich GD, Swanson LW. 2000. Organization of projections from the juxtacapsular nucleus of the BST: A PHAL study in the rat. Brain Res 859: 1-14.

Dong HW, Petrovich GD, Swanson LW. 2001a. Topography of projections from amygdala to bed nuclei of the stria terminalis. Brain Res Brain Res $\operatorname{Rev~38:~192-246.~}$

Dong HW, Petrovich GD, Watts AG, Swanson LW. 2001b. Basic organization of projections from the oval and fusiform nuclei of the bed nuclei of the stria terminalis in adult rat brain. J Comp Neurol 436: $430-455$.

Donley MP, Schulkin J, Rosen JB. 2005. Glucocorticoid receptor antagonism in the basolateral amygdala and ventral hippocampus interferes with long-term memory of contextual fear. Behav Brain Res 164: $197-205$.

Fendt M, Endres T, Apfelbach R. 2003. Temporary inactivation of the bed nucleus of the stria terminalis but not of the amygdala blocks freezing induced by trimethylthiazoline, a component of fox feces. J Neurosci 23: $23-28$.

Fendt M, Endres T, Lowry CA, Apfelbach R, McGregor IS. 2005a. TMT-induced autonomic and behavioral changes and the neural basis of its processing. Neurosci Biobehav Rev 29: 1145-1156.

Fendt M, Siegl S, Steiniger-Brach B. 2005b. Noradrenaline transmission within the ventral bed nucleus of the stria terminalis is critical for fear behavior induced by trimethylthiazoline, a component of fox odor. $J$ Neurosci 25: 5998-6004.

Gauriau C, Bernard JF. 2002. Pain pathways and parabrachial circuits in the rat. Exp Physiol 87: 251-258.

Gewirtz JC, McNish KA, Davis M. 1998. Lesions of the bed nucleus of the stria terminalis block sensitization of the acoustic startle reflex produced by repeated stress, but not fear-potentiated startle. Prog Neuropsychopharmacol Biol Psychiatry 22: 625-648.

Gomes FV, Reis DG, Alves FH, Correa FM, Guimaraes FS, Resstel LB. 2012. Cannabidiol injected into the bed nucleus of the stria terminalis reduces the expression of contextual fear conditioning via 5-HT1A receptors. J Psychopharmacol 26: 104-113.

Gray TS, Magnuson DJ. 1987. Neuropeptide neuronal efferents from the bed nucleus of the stria terminalis and central amygdaloid nucleus to the dorsal vagal complex in the rat. J Comp Neurol 262: 365-374.

Gray TS, Magnuson DJ. 1992. Peptide immunoreactive neurons in the amygdala and the bed nucleus of the stria terminalis project to the midbrain central gray in the rat. Peptides 13: 451-460.

Gray TS, Piechowski RA, Yracheta JM, Rittenhouse PA, Bethea CL, Van de Kar LD. 1993. Ibotenic acid lesions in the bed nucleus of the stria 
terminalis attenuate conditioned stress-induced increases in prolactin, ACTH and corticosterone. Neuroendocrinology 57: 517-524.

Green MK, Barbieri EV, Brown BD, Chen KW, Devine DP. 2007. Roles of the bed nucleus of stria terminalis and of the amygdala in $\mathrm{N} /$ OFQ-mediated anxiety and HPA axis activation. Neuropeptides 41: $399-410$.

Greenberg BD, Gabriels LA, Malone DA Jr., Rezai AR, Friehs GM, Okun MS, Shapira NA, Foote KD, Cosyns PR, Kubu CS, et al. 2010. Deep brain stimulation of the ventral internal capsule/ventral striatum for obsessive-compulsive disorder: Worldwide experience. Mol Psychiatry 15: $64-79$

Hammack SE, Richey KJ, Watkins LR, Maier SF. 2004. Chemical lesion of the bed nucleus of the stria terminalis blocks the behavioral consequences of uncontrollable stress. Behav Neurosci 118: 443-448.

Hammack SE, Cheung J, Rhodes KM, Schutz KC, Falls WA, Braas KM, May V. 2009. Chronic stress increases pituitary adenylate cyclase-activating peptide (PACAP) and brain-derived neurotrophic factor (BDNF) mRNA expression in the bed nucleus of the stria terminalis (BNST): Roles for PACAP in anxiety-like behavior. Psychoneuroendocrinology 34: $833-843$.

Hammack SE, Roman CW, Lezak KR, Kocho-Shellenberg M, Grimmig B, Falls WA, Braas K, May V. 2010. Roles for pituitary adenylate cyclase-activating peptide (PACAP) expression and signaling in the bed nucleus of the stria terminalis (BNST) in mediating the behavioral consequences of chronic stress. J Mol Neurosci 42: 327-340.

Han JS, Li W, Neugebauer V. 2005. Critical role of calcitonin gene-related peptide 1 receptors in the amygdala in synaptic plasticity and pain behavior. J Neurosci 25: 10717-10728.

Han JS, Adwanikar H, Li Z, Ji G, Neugebauer V. 2010. Facilitation of synaptic transmission and pain responses by CGRP in the amygdala of normal rats. Mol Pain 6: 10 .

Hasler G, Fromm S, Alvarez RP, Luckenbaugh DA, Drevets WC, Grillon C. 2007. Cerebral blood flow in immediate and sustained anxiety. $J$ Neurosci 27: 6313-6319.

Herman JP, Cullinan WE. 1997. Neurocircuitry of stress: Central control of the hypothalamo-pituitary-adrenocortical axis. Trends Neurosci 20: $78-84$

Herman JP, Cullinan WE, Watson SJ. 1994. Involvement of the bed nucleus of the stria terminalis in tonic regulation of paraventricular hypothalamic CRH and AVP mRNA expression. J Neuroendocrinol 6: $433-442$.

Hishinuma T, Asakura M, Nagashima H, Sasuga Y, Fujii S, Tanaka D, Kanai S. 2005. Effect of chronic variable stress on limbic corticotropin-releasing hormone receptor [Japanese]. Nihon Shinkei Seishin Yakurigaku Zasshi 25: 19-24.

Hokfelt T. 1991. Neuropeptides in perspective: The last ten years. Neuron 7: $867-879$.

Hokfelt T, Broberger C, Xu ZQ, Sergeyev V, Ubink R, Diez M. 2000. Neuropeptides-an overview. Neuropharmacology 39: 1337-1356.

Holstege G, Meiners L, Tan K. 1985. Projections of the bed nucleus of the stria terminalis to the mesencephalon, pons, and medulla oblongata in the cat. Exp Brain Res 58: 379-391.

Hott SC, Gomes FV, Fabri DR, Reis DG, Crestani CC, Correa FM, Resstel LB. 2012. Both $\alpha 1$ - and $\beta 1$-adrenoceptors in the bed nucleus of the stria terminalis are involved in the expression of conditioned contextual fear. Br J Pharmacol 167: 207-221.

Jennings JH, Sparta DR, Stamatakis AM, Ung RL, Pleil KE, Kash TL, Stuber GD. 2013. Distinct extended amygdala circuits for divergent motivational states. Nature 496: 224-228.

Jovanovic T, Phifer JE, Sicking K, Weiss T, Norrholm SD, Bradley B, Ressler KJ. 2011. Cortisol suppression by dexamethasone reduces exaggerated fear responses in posttraumatic stress disorder. Psychoneuroendocrinology 36: 1540-1552.

Jovanovic T, Norrholm SD, Davis J, Mercer KB, Almli L, Nelson AB, Cross D, Smith AD, Ressler KJ, Bradley B. 2013. PAC1 receptor (ADCYAP1R1) genotype is associated with dark-enhanced startle in children. Mol Psychiatry 18: 742-743.

Ju G. 1991. Calcitonin gene-related peptide-like immunoreactivity and its relation with neurotensin- and corticotropin-releasing hormone-like immunoreactive neurons in the bed nuclei of the stria terminalis in the rat. Brain Res Bull 27: 617-624.

Ju G, Swanson LW, Simerly RB. 1989. Studies on the cellular architecture of the bed nuclei of the stria terminalis in the rat: II. Chemoarchitecture. J Comp Neurol 280: 603-621.

Keene ON. 1995. The log transformation is special. Stat Med 14: 811-819.

Kim SY, Adhikari A, Lee SY, Marshel JH, Kim CK, Mallory CS, Lo M, Pak S, Mattis J, Lim BK, et al. 2013. Diverging neural pathways assemble a behavioural state from separable features in anxiety. Nature 496: 219-223.

Kocorowski LH, Helmstetter FJ. 2001. Calcitonin gene-related peptide released within the amygdala is involved in Pavlovian auditory fear conditioning. Neurobiol Learn Mem 75: 149-163.
Kozicz T, Arimura A. 2001. Axon terminals containing CGRPimmunoreactivity form synapses with CRF- and Met-enkephalinimmunopositive neurons in the laterodorsal division of the bed nucleus of the stria terminalis in the rat. Brain Res 893: 11-20.

Kruger L, Mantyh PW, Sternini C, Brecha NC, Mantyh CR. 1988. Calcitonin gene-related peptide (CGRP) in the rat central nervous system: Patterns of immunoreactivity and receptor binding sites. Brain Res 463: 223-244.

Lebow M, Neufeld-Cohen A, Kuperman Y, Tsoory M, Gil S, Chen A. 2012. Susceptibility to PTSD-like behavior is mediated by corticotropin-releasing factor receptor type 2 levels in the bed nucleus of the stria terminalis. J Neurosci 32: 6906-6916.

Lee Y, Davis M. 1997. Role of the hippocampus, bed nucleus of the stria terminalis and amygdala in the excitatory effect of corticotropin releasing hormone on the acoustic startle reflex. J Neurosci 17: 6434-6446.

Lee Y, Fitz S, Johnson PL, Shekhar A. 2008. Repeated stimulation of CRF receptors in the BNST of rats selectively induces social but not panic-like anxiety. Neuropsychopharmacology 33: 2586-2594.

Lesur A, Gaspar P, Alvarez C, Berger B. 1989. Chemoanatomic compartments in the human bed nucleus of the stria terminalis. Neuroscience 32: 181-194.

Luyten L, van Kuyck K, Vansteenwegen D, Nuttin B. 2011. Electrolytic lesions of the bed nucleus of the stria terminalis disrupt freezing and startle potentiation in a conditioned context. Behav Brain Res 222: $357-362$.

Luyten L, Casteels C, Vansteenwegen D, van Kuyck K, Koole M, Van Laere K, Nuttin B. 2012. Micro-positron emission tomography imaging of rat brain metabolism during expression of contextual conditioning. J Neurosci 32: 254-263.

Miles L, Davis M, Walker D. 2011. Phasic and sustained fear are pharmacologically dissociable in rats. Neuropsychopharmacology 36: $1563-1574$

Miserendino MJD, Sananes CB, Melia KR, Davis M. 1990. Blocking of acquisition but not expression of conditioned fear-potentiated startle by NMDA antagonists in the amygdala. Nature 345: 716-718.

Moga MM, Saper CB, Gray TS. 1989. Bed nucleus of the stria terminalis: Cytoarchitecture, immunohistochemistry, and projection to the parabrachial nucleus in the rat. J Comp Neurol 283: 315-332.

Morilak DA, Cecchi M, Khoshbouei H. 2003. Interactions of norepinephrine and galanin in the central amygdala and lateral bed nucleus of the stria terminalis modulate the behavioral response to acute stress. Life Sci 73: 715-726.

Nagashima H, Asakura M, Hishinuma T, Tanaka D, Fujii S. 2003. Reduction and sensitization of CRH neuron in rat hypothalamic and extrahypothalamic regions after chronic variable stress [Japanese]. Nihon Shinkei Seishin Yakurigaku Zasshi 23: 21-28.

Paxinos G, Watson C. 1998. The rat brain in stereotaxic coordinates, 4th ed. Academic Press, New York.

Peyron C, Petit JM, Rampon C, Jouvet M, Luppi PH. 1998. Forebrain afferents to the rat dorsal raphe nucleus demonstrated by retrograde and anterograde tracing methods. Neuroscience 82: 443-468.

Ressler KJ, Mercer KB, Bradley B, Jovanovic T, Mahan A, Kerley K, Norrholm SD, Kilaru V, Smith AK, Myers AJ, et al. 2011. Post-traumatic stress disorder is associated with PACAP and the PAC1 receptor. Nature 470: $492-497$.

Resstel LB, Alves FH, Reis DG, Crestani CC, Correa FM, Guimaraes FS. 2008. Anxiolytic-like effects induced by acute reversible inactivation of the bed nucleus of stria terminalis. Neuroscience 154: 869-876.

Roman CW, Lezak KR, Kocho-Schellenberg M, Garret MA, Braas K, May V, Hammack SE. 2012. Excitotoxic lesions of the bed nucleus of the stria terminalis (BNST) attenuate the effects of repeated stress on weight gain: Evidence for the recruitment of BNST activity by repeated, but not acute, stress. Behav Brain Res 227: 300-304.

Roozendaal B. 2002. Stress and memory: Opposing effects of glucocorticoids on memory consolidation and memory retrieval. Neurobiol Learn Mem 78: 578-595.

Ruxton GD. 2006. The unequal variance $t$-test is an underused alternative to Student's $t$-test and the Mann-Whitney U test. Behav Ecol 17: $688-690$.

Sahuque LL, Kullberg EF, McGeehan AJ, Kinder JR, Hicks MP, Blanton MG, Janak PH, Olive MF. 2006. Anxiogenic and aversive effects of corticotropin-releasing factor (CRF) in the bed nucleus of the stria terminalis in the rat: Role of CRF receptor subtypes. Psychopharmacology 186: $122-132$.

Santibanez M, Gysling K, Forray MI. 2006. Desipramine prevents the sustained increase in corticotropin-releasing hormone-like immunoreactivity induced by repeated immobilization stress in the rat central extended amygdala. I Neurosci Res 84: 1270-1281.

Sarhan M, Freund-Mercier MJ, Veinante P. 2005. Branching patterns of parabrachial neurons projecting to the central extended amygdala: Single axonal reconstructions. J Comp Neurol 491: 418-442. 
Schelling G, Roozendaal B, Krauseneck T, Schmoelz M, de Quervain D, Briegel J. 2006. Efficacy of hydrocortisone in preventing posttraumatic stress disorder following critical illness and major surgery. Ann N Y Acad Sci 1071: 46-53.

Schweimer J, Fendt M, Schnitzler HU. 2005. Effects of clonidine injections into the bed nucleus of the stria terminalis on fear and anxiety behavior in rats. Eur J Pharmacol 507: 117-124.

Shepard JD, Chambers CO, Busch C, Mount A, Schulkin J. 2009. Chronically elevated corticosterone in the dorsolateral bed nuclei of stria terminalis increases anxiety-like behavior. Behav Brain Res 203: 146-149.

Shimada S, Shiosaka S, Emson PC, Hillyard CJ, Girgis S, MacIntyre I, Tohyama M. 1985. Calcitonin gene-related peptidergic projection from the parabrachial area to the forebrain and diencephalon in the rat: An immunohistochemical analysis. Neuroscience 16: 607-616.

Sink KS, Walker DL, Yang Y, Davis M. 2011. Calcitonin gene-related peptide in the bed nucleus of the stria terminalis produces an anxiety-like pattern of behavior and increases neural activation in anxiety-related structures. J Neurosci 31: 1802-1810.

Sink KS, Chung A, Ressler KJ, Davis M, Walker DL. 2013. Anxiogenic effects of CGRP within the BNST may be mediated by CRF acting at BNST CRFR1 receptors. Behav Brain Res 243: 286-293.

Skofitsch G, Jacobowitz DM. 1985. Autoradiographic distribution of 125I calcitonin gene-related peptide binding sites in the rat central nervous system. Peptides 6: 975-986.

Somerville LH, Whalen PJ, Kelley WM. 2010. Human bed nucleus of the stria terminalis indexes hypervigilant threat monitoring. Biol Psychiatry 68: $416-424$.

Somerville LH, Wagner DD, Wig GS, Moran JM, Whalen PJ, Kelley WM. 2013. Interactions between transient and sustained neural signals support the generation and regulation of anxious emotion. Cereb Cortex 23: $49-60$.

Soravia LM, Heinrichs M, Aerni A, Maroni C, Schelling G, Ehlert U, Roozendaal B, de Quervain DJ. 2006. Glucocorticoids reduce phobic fear in humans. Proc Natl Acad Sci 103: 5585-5590.

Sterrenburg L, Gaszner B, Boerrigter J, Santbergen L, Bramini M, Elliott E, Chen A, Peeters BW, Roubos EW, Kozicz T. 2011. Chronic stress induces sex-specific alterations in methylation and expression of corticotropin-releasing factor gene in the rat. PLoS One 6: e28128.

Straube T, Mentzel HJ, Miltner WH. 2007. Waiting for spiders: Brain activation during anticipatory anxiety in spider phobics. Neuroimage 37: $1427-1436$.

Sullivan GM, Apergis J, Bush DE, Johnson LR, Hou M, Ledoux JE. 2004. Lesions in the bed nucleus of the stria terminalis disrupt corticosterone and freezing responses elicited by a contextual but not by a specific cue-conditioned fear stimulus. Neuroscience 128: 7-14.

Taubenfeld SM, Riceberg JS, New AS, Alberini CM. 2009. Preclinical assessment for selectively disrupting a traumatic memory via postretrieval inhibition of glucocorticoid receptors. Biol Psychiatry 65: $249-257$.
Tronel S, Alberini CM. 2007. Persistent disruption of a traumatic memory by postretrieval inactivation of glucocorticoid receptors in the amygdala. Biol Psychiatry 62: 33-39.

Waddell J, Morris RW, Bouton ME. 2006. Effects of bed nucleus of the stria terminalis lesions on conditioned anxiety: Aversive conditioning with long-duration conditional stimuli and reinstatement of extinguished fear. Behav Neurosci 120: 324-336.

Walker DL, Davis M. 1997. Double dissociation between the involvement of the bed nucleus of the stria terminalis and the central nucleus of the amygdala in light-enhanced versus fear-potentiated startle. J Neurosci 17: $9375-9383$.

Walker DL, Davis M. 2002a. Quantifying fear potentiated startle using absolute versus percent increase scoring methods: Implications for the neurocircuitry of fear and anxiety. Psychopharmacology 164: $318-328$.

Walker DL, Davis M. 2002b. The role of glutamate receptors within the amygdala in fear learning, fear-potentiated startle, and extinction. Pharmacol Biochem Behav 71: 379-392.

Walker DL, Miles LA, Davis M. 2009. Selective participation of the bed nucleus of the stria terminalis and CRF in sustained anxiety-like versus phasic fear-like responses. Prog Neuropsychopharmacol Biol Psychiatry 33: 1291-1308.

Walter A, Mai JK, Lanta L, Gorcs T. 1991. Differential distribution of immunohistochemical markers in the bed nucleus of the stria terminalis in the human brain. J Chem Neuroanat 4: 281-298.

Welch BL. 1938. The significance of the difference between two means when the population variances are unequal. Biometrika 29: 350-362.

Woodhams PL, Roberts GW, Polak JM, Crow TJ. 1983. Distribution of neuropeptides in the limbic system of the rat: The bed nucleus of the stria terminalis, septum and preoptic area. Neuroscience 8: 677-703.

Xu HY, Liu YJ, Xu MY, Zhang YH, Zhang JX, Wu YJ. 2012. Inactivation of the bed nucleus of the stria terminalis suppresses the innate fear responses of rats induced by the odor of cat urine. Neuroscience 221: 21-27.

Yassa MA, Hazlett RL, Stark CE, Hoehn-Saric R. 2012. Functional MRI of the amygdala and bed nucleus of the stria terminalis during conditions of uncertainty in generalized anxiety disorder. J Psychiatr Res 46: 1045-1052.

Zimmerman JM, Maren S. 2011. The bed nucleus of the stria terminalis is required for the expression of contextual but not auditory freezing in rats with basolateral amygdala lesions. Neurobiol Learn Mem 95: 199-205.

Zohar J, Yahalom H, Kozlovsky N, Cwikel-Hamzany S, Matar MA, Kaplan Z, Yehuda R, Cohen H. 2011. High dose hydrocortisone immediately after trauma may alter the trajectory of PTSD: Interplay between clinical and animal studies. Eur Neuropsychopharmacol 21: 796-809.

Received July 15, 2013; accepted in revised form October 6, 2013. 


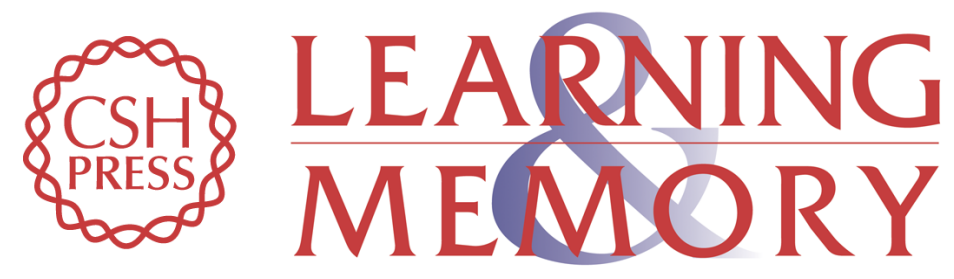

\section{CGRP antagonist infused into the bed nucleus of the stria terminalis impairs the acquisition and expression of context but not discretely cued fear}

Kelly S. Sink, Michael Davis and David L. Walker

Learn. Mem. 2013, 20:

Access the most recent version at doi:10.1101//m.032482.113

References This article cites 109 articles, 13 of which can be accessed free at: http://learnmem.cshlp.org/content/20/12/730.full.html\#ref-list-1

Creative This article is distributed exclusively by Cold Spring Harbor Laboratory Press for the Commons first 12 months after the full-issue publication date (see License $\mathrm{http} / / /$ learnmem.cshlp.org/site/misc/terms.xhtml). After 12 months, it is available under a Creative Commons License (Attribution-NonCommercial 3.0 Unported), as described at http://creativecommons.org/licenses/by-nc/3.0/.

Email Alerting Receive free email alerts when new articles cite this article - sign up in the box at the Service top right corner of the article or click here. 